\title{
On the Road to Multiculturalism
}

\author{
By Gisela Hoecherl-Alden \\ Spring 2006 Issue of KINEMA

\section{ON THE ROAD TO MULTICULTURALISM: CHALLENGING CONCEPTS OF NEU- TRALITY AND TOLERANCE IN SWISS-GERMAN CIEMA}

Switzerland, which prides itself on its political neutrality, democratic ethos and multilingualism, has long been celebrated as a unique model for the peaceful co-existence of diverse cultural groups residing within autonomous cantons (see Altermatt et. al. 1998). Yet by exploring the national culture, transgressing boundaries, and mapping life-transforming experiences, three Swiss-German films challenge this commonly accepted image of their nation. Although not road movies in the sense that the primary movement is shot from a vehicle's point of view (see Laderman 2002: 13), the films Die Schweizermacher (The Swissmakers, Switzerland, 1978) by Rolf Lyssy, Reise der Hoffnung (Journey of Hope, Switzerland-Turkey, 1990) by Xavier Koller, and Pastry, Pain and Politics (Switzerland, 1998) by Stina Werenfels nevertheless integrate road imagery and mobility into their political and visual narratives. The journeys undertaken are "a means of cultural critique", which aims "beyond the borders of cultural familiarity", and are simultaneously "symptomatic of postmodern anxiety and restlessness" (see Laderman 2002: 1-2). Hence the road, and not a vehicle travelling upon it, "provides a performative space for imaginative revisions of identity and society" (see Mills, 1997: 307).

The growing number of European road films ${ }^{(1)}$ coincides with a tightening of immigration restrictions brought about by mass migrations across Europe's borders and lends credence to Cohan and Hark's remark, that times of crisis provoke accelerated road movie production (see Cohan \& Hark, 1997: 8-13). While Mazierska's critique of two German road movies which explore the geographic margins of Europe from an ethnocentric viewpoint, establishes that the directors essentially ignore the reality of a multicultural Germany and thus avoid a renegotiation of their European identities (see Mazierska 2001), ${ }^{(2)}$ the films by Lyssy, Koller and Werenfels clearly question the nature of Switzerland's self-proclaimed cultural diversity.

\section{Immigrants in Culturally Diverse Switzerland}

Since the 1870s, when workers were first recruited for the construction of alpine tunnels and railroads, Switzerland's economic stability has relied heavily on immigrant labour. According to Afonso, the country's lack of raw materials has ensured its dependency on foreign goods, science, capital, markets and workers, while the traditional image insists on the industriousness, independence and seriousness of its citizens (see Afonso 2004: 165). During the 1920s, as Häsler reports, strong economic ties to its fascist neighbour prompted the Swiss government to propose the introduction of the "J" stamp for German-Jewish passports to Berlin, thus ensuring that the visa restrictions did not affect non-Jewish German nationals. Furthermore, by invoking the image of a full life boat ("das Boot ist voll"), Switzerland justified Jewish refugees' forceful return to Germany (see Häsler 1968).

In need of labourers again after the war, Switzerland re-opened its borders and during the 1950s and 1960s Italian migrants found employment mostly, as Afonso points out, in construction, catering, hotels and factories. They were, however, only issued seasonal or annual work permits, since the outspokenly communist Italian labour unions were perceived as a threat to Switzerland's stability during the Cold War (see Afonso 2004: 153). Simultaneously, the country proudly provided safe haven for refugees from Communist Hungary and Czechoslovakia. As a result, nearly $19 \%$ of the country's population was foreign-born by the late 1960s, and with a stagnant economy compounded by the oil crisis, fear of Überfremdung (over-alienation) grew. In fact, as Afonso states, "massive immigration movements in Switzerland have led to considerable xenophobic reactions among the Swiss population, and direct democracy has been a very specific means of expressing this xenophobia at the political level" (see Afonso 2004: 149).

In 1970, the right-wing conservative James Schwarzenbach proposed parliamentary action on the expulsion of one third of the country's foreign labour force to ensure that aliens compose no more than $10 \%$ of the population, thus creating the first major anti-immigrant movement in Europe. Although narrowly defeated, 
Afonso suggests the threat of parliamentary action through direct democracy prompted the government to impose a quota for work permits and shift enforcement power to the cantonal administrations (see Afonso 2004: 154). Pride in the humanitarian tradition of providing asylum to the oppressed also rapidly waned as large numbers of refugees began arriving from Sri Lanka, Turkey, Somalia, Angola, Serbia, Kosovo, and Bosnia in the 1980s and 1990s. In fact, as Gibson concludes in her comparative analysis of Western European nations and their stance towards immigrants, naturalization is probably most difficult in Switzerland, where anti-immigrant politics have been more numerous, vocal and long lasting than in any other Western European nation (see Gibson 2002).

Although Altermatt describes Switzerland as a multicultural, multiethnic nation based on "political will" (see Altermatt 1996: 145), much like Anderson's imagined community with a shared national identity, secure sense of belonging in a geopolitical space (see Anderson 1983), immigrants receive the permanent status of Ausländer (foreigner). They are expected to assimilate rather than preserve of their own culture in the way ethnic German, French, Italian and Romansch, as Swiss citizens do. Yet if, as Altermatt suggests, Switzerland does not subscribe to an ethnic concept of nation based on a community of biological descent (ius sanguinis) with a common culture and history (see Castles and Miller 2003), why is the cultural 'otherness' of its immigrants continuously seen as a threat to the very fabric of Swiss society? It is, after all, the ethnic and not civic idea of nation that is invoked through the concept of Überfremdung, which plays such an important role in discourses on Swiss immigration.

Apparently, when applied to immigrants, the ethnic concept of nation overrides the multicultural imagined nation of will. In addition, as Ludi states, the country's notion of "highly moralized" (126) neutrality linked to alleged humanitarian achievements during the Cold War is the key to Swiss self-definition, which, along with the strong belief in the deterring power of its army, also serves to explain why Switzerland remained unscathed during the war. This self-perception is nurtured by emphasizing those aspects of Swiss history, which exemplify heroic struggles for freedom and political independence as an element crucial to Swiss identity. Narrating the Swiss nation from this vantage point, therefore presents Switzerland secluded from the rest of the world. This public image underscores the country's policy of neutrality in the dualistic world after 1945 and justifies the central position of the army in Swiss society (see Ludi 2004: 119-126).

\section{The Swissmakers: How to be(come) Swiss}

A few years after the Schwarzenbach-referendum Rolf Lyssy made his comedy The Swissmakers, a satirical commentary on multilingual Switzerland as a tolerant and culturally diverse nation. Although no-one ever actually leaves the city of Zurich, the act of travelling determines the film narrative. Max Bodmer, a monolingual veteran immigration officer, and Moritz Fischer, his apprentice, travel the streets of Zurich by car, on foot, and by streetcar to interview and also spy on various applicants for Swiss citizenship. The candidates for naturalization assigned to Bodmer and Fischer are an Italian baker, Francesco Grimolli, a German physician and his wife, Helmut and Gertrud Starke, and a Yugoslav dancer, Milena Vakulic. Each represents a different category of immigrant: the wealthy and highly skilled German (on the influx of welltrained immigrants from Western Europe and the United States see Afonso 2004: 164), the Italian labour migrant who works in the catering industry, and the refugee from the Eastern bloc, albeit Swiss-born. The first names of the cantonal immigration officers allude to Wilhelm Busch's mischievous pair of $19^{\text {th }}$ century comic strip fools Max and Moritz, and like the comic strip series, the film is episodic in structure.

The movie begins with the head of the cantonal immigration authority informing his officers and their trainees that an assimilated foreigner is someone who is no longer noticeable. Eliciting adjectives, that describe a true citizen of Switzerland, the trainees provide him with "dependable," "neutral," "serious," "righteous," "hard-working," and "militant", after which they begin their quest for those worthy of Swiss citizenship. In one form or another, these Swiss stereotypes surface throughout the movie and sustain Lyssy's question as to what being Swiss or becoming Swiss really means, and whether unconditional assimilation at the price of cultural identity should be the stated goal of immigration policies. From the beginning, Fischer and Bodmer are at odds about the nature of their assignment. While Fischer is genuinely interested in the applicants, Bodmer sets out to prove that most of them are deficient in some way and not worthy of naturalization. Since Bodmer treats each applicant differently, Lyssy also exposes racism inherent to immigration rulings.

While shadowing the German physician, the men walk on a street paved with golden letters spelling the word 
"bank". When Fischer jokes about Switzerland's pre-occupation with money, Bodmer chastises him by stating that the country's wealth is well-deserved ("von nichts kommt nichts"). As if emphasizing his comment, a golden streetcar passes by behind him. The imagery suggests that the wealthy German couple's passage to Swiss citizenship, their pathetic attempts at Swiss cuisine and speaking the Swiss dialect notwithstanding, will go smoothly. Ironically, on their way to the final interview, the German couple not only breaks every possible traffic rule, but also arrives late. Nevertheless, the entire cantonal immigration committee is prepared to overlook any lapses and admits the Germans to their national community, because - according to prevailing national stereotypes - Germans are punctual and dependable.

Despite the fact that he has been living in Switzerland for twelve years and is married to an ethnic SwissItalian woman, Bodmer remains suspicious of Grimolli. In an attempt to sway the immigration officer's opinion, Grimolli invokes the national myth of Wilhelm Tell. Pointing to a family photograph taken in front of the famous Tell-statue in Altdorf, he emotionally asks who wouldn't want to live in a country that produces such freedom fighters. Almost as an afterthought he adds that his Swiss wife would like to continue living in her homeland. Although temporarily appeased ("so etwas hört man nicht oft") Bodmer soon trails him again, in an effort to prove that Grimolli, like all Italians, is a communist. When his employer enthusiastically praises Grimolli for his superb work ethic and, most of all, for his friendly and cheerful disposition, Bodmer mumbles that he needs to assimilate ("anpassen muss er sich"), and thus invokes the Swiss stereotype of seriousness. Lacking proof, Bodmer finally recommends Grimolli for Swiss citizenship. On the day he becomes naturalized, the family and friends hug and kiss Bodmer, and enthusiastically launch into Italy's communist anthem, Bandiera rossa. However, since Bodmer does not understand Italian - one of Switzerland's official languages - he remains oblivious and merely shakes his head at such a display of un-Swiss enthusiasm.

It is the single, Swiss-born Yugoslav dancer Milena Vakulic, whom Bodmer harasses at unsuitable times with invasive questions. Choosing a Yugoslav rather than a Czech or Hungarian immigrant, Lyssy plays on the Western notion of the Balkans as a less civilized part of Europe. As Todorova has argued, this binary discourse strategy, both exoticizing and demonizing, serves to represent the Balkans as "a repository for negative characteristics" against which to construct "a positive and self-congratulatory image" of Western Europe (see Todorova 1994: 453). Bodmer therefore jumps to absurd conclusions and equates Milena's friendship with a Turkish colleague as evidence of a drug habit. The episodes involving her also evoke the stereotype of Swiss righteousness, or rather self-righteousness.

Outraged neighbours state that the non-conformist artist refuses to adapt to the ways of the majority citing her not hanging curtains in front of her windows and insisting on using brown instead of black trash bags as major infractions. Worst of all, she has foreign, possibly Russian, friends. It is in these sections that Lyssy exposes the complicity and xenophobia of the general Swiss population. Much like the Swiss government's reactions to public referenda, Bodmer is egged on by the neighbours' opinions, and his surveillance methods and questions become ever more sexist and inappropriate.

Initially a willing apprentice, Fischer's journey through multicultural Zurich leads to his disillusionment with his canton's immigration policies. He finally decides to leave the force and follow Milena, who has given up on obtaining Swiss citizenship altogether, to the Netherlands, while Bodmer continues his quest with a new trainee. The film ends with a visit to the most recent applicant, an American musician, who unlike the previous candidates for citizenship, not only does not speak a single one of Switzerland's four languages, but to Bodmer's disgust, lives without furniture and, upon their arrival, proceeds to play a jazz version of the Swiss national anthem. The film ends with the new trainee moving to the rhythm of the saxophone, while Bodmer is revealed as hopelessly out of touch with a changing Switzerland, his rules no longer applicable to the reality of a multicultural immigrant nation.

\section{Crossing Borders to Picture-Perfect Switzerland: Journey of Hope}

Filmic journeys undertaken to escape political or economic hardship often lead from the rural south to a north perceived as liberating, and usually come at the cost of losing one's cultural identity and family ties. ${ }^{(3)}$ Such films also clearly trace, as Laderman states, travels into a national culture, rather than outside of it. The journeys are negotiated from the protagonists' marginalized social status and the films thus try to revise mainstream stereotypes about the ethnic groups in question (see Ladermann 2001: 232-48). 
Migration becomes a painful, disquieting experience, where changing places results in harsh confrontations, and, according to Iordanova, leads from one marginal or peripheral place to another. The journeys in these road movies no longer begin with liberating escapes from restrictions (see Iordanova 2001). The tightening of European immigration regulations has forced potential migrants to choose clandestine pathways and avail themselves of transnational coyote networks. The outcomes of these migration attempts are often tragic, and one of the first in a growing body of films denouncing traffic in humans is Xavier Koller's Journey of Hope, which not only garnered an academy award for best foreign film in 1991, but was also recently screened at the $2^{\text {nd }}$ International Festival on Human Rights in Geneva (see: Festival International du Film sur les Droits Humains 2004).

Xavier Koller begins his Journey of Hope in the desperately poor Kurdish region of Turkey, where a post card image of lush vegetation and snow-covered mountains is contrasted to the barren, dusty landscape. The short text tells of a relative's economic success in Switzerland and how easy it is to get there. The card inspires Haydar to sell his livestock and land, leave six of his children in the care of his family, and take his wife and youngest son to the perceived land of plenty. Naficy includes Koller's film among the works of "accented cinema" because of its diasporic and exilic subject matter (see Naficy 2001: 23) and not so much because of "the accented speech of the diegetic characters" (4).

What Naficy also finds intriguing about accented film narratives is their "epistolarity, involving the use of the formal properties of letters ... to create and exchange meaning". The postcard therefore creates "an illusion of presence" in the film's "interstices" (5) as well as the "desire to be with an other and to reimagine an elsewhere" (101). Acting upon this desire, the family gets caught up in a net of unscrupulous traffickers who make their living shuttling Kurds through Istanbul to Italy and then on foot over the Swiss border. The loss of cultural ties predicted by Haydar's father, who opposes his son's move north, manifests itself almost immediately. Visually, Koller underscores the transition from a rooted to an uprooted existence by alternating transitional seaports, train stations, highway gas stations, and wide open landscapes with claustrophobic, closed spaces in busses, ships and trucks. Soon joined by other compatriots, it becomes clear that by the time they reach Northern Italy they neither know where they are, nor can they any longer determine where Mecca is.

Although Journey of Hope is a Swiss-Turkish co-production, the story is clearly told from the Swiss perspective, by which immigration is presented as culture shock, and the migrant becomes an alienated, speechless victim. Like other "accented" films, Koller uses not only the journey, but also luggage as a symbol for transition and exile. On the last part of their trip, the arduous climb over the mountains, the travellers realize that their suitcases and bundles endanger their progress and "hurl them into the valleys below. As some of the suitcases burst open, releasing their contents into the air, we, as well as the refugees realize that with that seemingly simple act of unburdening, they have also discarded some of their past and frayed some of their connections of their culture and homeland" (see Naficy 2001: 266). When the group arrives in a Swiss mountain village, Koller visually recreates the post card, which lured Haydar and his family to Switzerland in the first place and recasts it as a powerful image of exclusion: as the exhausted, freezing immigrants stand in the snow, mountains behind them, they look through the glass at the lush greenery surrounding an indoor swimming pool from which the owner yells the word "closed" ("geschlossen!").

The catastrophic ending does not exonerate the Swiss authorities, who charge Haydar with illegal entry to Switzerland and reckless endangerment of his son. When they ask "who and what brought you here?" trying to find out more about the coyote network, he simply answers "hope". The translator's deliberate ambiguity serves to criticize the immigration authorities' stubborn adherence to rules in the face of the human tragedy. When he asks the officer: "How could he have known that this place is so cold?" he is clearly referring to the cold-heartedness of the Swiss authorities, which Koller also underscores visually through the brilliantly white sterility of the prison. Throughout the journey, Koller explores the significance of border crossings - both figurative and real, and uses melodrama to interweave the political with the intensely personal. Reading Koller's film as a dialogue between Kurdish and Swiss society and focusing on ethnic and racial identities Switzerland, it is "contestatory" (15), like many an accented film (see Naficy 2001: 6-15). He absolves the migrants, who are gullible, naive, and finally speechless, driven by the desire to make a better life for themselves, but denounces the immorality and inhumanity of coyote networks as well as immigration authorities of wealthy countries like his own. As the road to leads to catastrophe, Koller offers a scathing 
critique of an ideologically positioned humanitarianism, and, like Lyssy and other Swiss film makers, ${ }^{(4)}$ questions the nature of Switzerland's self-proclaimed neutrality and multiculturalism in the face of mass migrations and displacements.

\section{On the Road to Intercultural Communication: Pastry, Pain and Politics}

Stina Werenfels made her award-winning short film Pastry, Pain, and Politics (Switzerland, 1998) at the height of the international scandal surrounding Swiss banks and dormant Holocaust victim's accounts, during which the country "experienced a shocking outburst of anti-Semitism" (see Ludi 2004: 122) and unerringly unmasks a variety of stereotypes and racist attitudes held by citizens, tourists and refugees alike. She begins her film with the arrival of the Weintraubs, a Jewish couple from New York, who are planning to spend their summer vacation in Switzerland because, as Fritz Weintraub puts it, "Israel is too hot, there are too many Arabs, and all Arabs are terrorists." For his wife Ellen, a Holocaust survivor, Germany is not an option but she also has bad memories of Switzerland's closed borders during World War II. As they sit in a café Fritz gets sick from eating too much rich pastry and is hospitalized.

When he finds out that his nurse, Hayat, is Palestinian, he adamantly demands a replacement. The SwissGerman doctor pulls Hayat aside, tells her "if I can treat Jews, so can you" ("Wenn ich Juden behandeln kann, können Sie das auch"), and threatens not to sign her work permit renewal if she does not do a better job controlling her patients. A German couple, whom Fritz categorically refers to as storm troopers, persuades Ellen to take a trip to the Rhine. Hayat, who has the afternoon off, receives a ticket for the same tour from a co-worker. Mid-trip both women realize that they will have to cross the border into Germany. Both panic for different reasons, and when the tour guide refuses to let them out, Hayat uses what she knows are commonly held stereotypes of Palestinians to her advantage to achieve her goal of stopping the bus. As the two women try to find their way back through the woods, they fight about Israel, Palestine and the Holocaust.

A cuckoo's mating call heard in the background not only indicates that it is Spring, a season of renewal, but also seems to mock their highly charged debate. Briefly detained, shaken by uniformed authority, the two women bond, both using Ellen's US passport to cross the much-feared border. Ellen finds that she can, after all, set a foot in Germany, releasing long-held psychological tension and Hayat captures her emotional victory on video. On their way back, Ellen purchases a cuckoo clock for Fritz, but by the time they arrive at the hospital, she agrees with Hayat that the clock is ugly and deposits it in a trash can.

Werenfels clearly re-evaluates the country's popular image of an island unto itself. Her film provides a visual context for the diplomatic crisis resulting from the bank scandal, which, as Ludi states, illustrated the political unfeasibility of neutrality in an increasingly interconnected world while simultaneously unmasking domestic intolerance toward minorities (see Ludi 2004: 124). International outrage over Switzerland's involvement in the crimes of the Nazi regime, and the fact that the request for J-stamped passports indicated the country's acceptance of the racist Nürnberg Laws, irrevocably shattered the image of Switzerland as a neutral and independent country with a strong humanitarian tradition. According to Wiedmer, this precipitated a "crisis of national self-assessment" (see Wiedmer 2002: 467), in which the country was bitterly divided along generational, racial and political lines.

Furthermore, she argues that the connection between image and site is an important factor in the production of cultural narratives of memory and national memory politics. In Switzerland, unlike Germany and Austria, the absence of such visible sites of perpetration allowed official Swiss agencies to ignore mounting indices of Switzerland's dealings with the Third Reich until the 1990s, when the Swiss site of perpetration came to be recognized as its border (see Wiedmer 2002: 466-477). Just as the documentaries made in the wake of the Swiss bank scandal do, ${ }^{(5)}$ Pastry, Pain and Politics very much focuses on borders and border crossings. At the end of the film, satirizing the Swiss iconography of precision clockwork, the clock's cuckoo ridicules both the authorities investigating the ticking trash can and the viewers. In using this metaphor, Werenfels avails herself of the multi-layered symbolism associated with the cuckoo, which is, after all, a parasite. Apart from the allusion to foolishness, the bird also stands for the claim of a collecting agency. Werenfels thus effectively criticizes both right-wing anti-foreigner campaigns, which routinely depict asylum seekers as parasitic "gangsters, drug dealers or at least cheats" who "abuse Swiss hospitality" (see Afonso 2004: 158) as well as those who denounce repayment of Holocaust debts as "Shoah business" (see Ludi 2004: 117).

\section{Conclusion}


For Lyssy, Koller and Werenfels the road becomes the space where Swiss authorities are either challenged or a revision of previously held beliefs takes place. If one applies Webster's definition of a fool as a "person lacking in judgment or prudence", Max Bodmer's road remains circuitous and indicates that he, much like the authorities he represents, seems impervious to change. On the other hand, Moritz Fischer, who is genuinely concerned for the applicants, is a fool in the sense of "one with a marked propensity of fondness for something". Travelling the streets of Zurich provides him with insights, which eventually lead him to reject the immigration authority's rigid rules and intrusive methods. His road, together with Swiss-born Milena's, therefore ironically leads out of Switzerland altogether. It is the third definition of a fool as "one who is made to appear foolish" which serves as a satire on Swiss diversity and linguistic pluralism, since Bodmer's lack of Italian proficiency causes the naturalization of a so-called undesirable.

Conversely, Koller's treacherous road north for clandestine immigrants leads to cultural loss, displacement, incarceration, and deportation. No longer portrayed as inept fools, the stationary authorities, who have not benefited from a transformative journey, are seen as insensitive and callous, and so steeped in rules that they are incapable of flexibility. In terms of the growing divide between the rich and poor countries, Koller clearly appeals for a change in immigration policies.

He too, comments on the importance of language, by portraying the monolingual border guards as so literalminded that they do not even pick up on the subtleties of their own language. Finally, the route taken by the two women, and Fritz by way of Hayat's video, in Pastry, Pain, and Politics includes both personal and literal border crossings and becomes a first step towards healing and intercultural communication. The cherished myth of political neutrality shattered, the resulting identity crisis opens up the possibility for "a cultural liminality within the nation" (see Bhabha 1994: 148). Ironically, in Werenfels' film the foreigners and not the Swiss citizens are the ones who avail themselves of the opportunity to come to an understanding and move towards an imagined transnational sense of community. Hayat, Ellen, and Fritz briefly become co-travellers in the "borderlines of nation-space" (see Bhabha 1994: 145). While arguing on a road in the no-man's land between Switzerland and Germany, outside of the complexities of cultural identity, they find themselves in the "interstices, the overlap and displacement of domains of difference" where cultural values are negotiated "despite shared histories of deprivation and discrimination" (see Bhabha 1994: 2).

The Swiss doctor and Fritz' roommate, on the other hand, remain firmly grounded in the ethnic concept of nation. The film is multilingual (Swiss German, High German, English, Arabic and Yiddish), and, like Koller's and Lyssy's, criticizes monolingual intolerance and incapability for communication in the person of Fritz' roommate, who believes Yiddish to be a strange Swiss dialect ("Ja, was ist das denn für ein Dialekt?"). Afonso interprets the perpetual fear of Überfremdung as a fear of losing a Swiss national identity that has been constructed as a defence mechanism to protect the country from inclusion in its neighbours' conflicts. However, since three of the four official languages spoken in Switzerland are also spoken by its neighbours there is a constant need for differentiation between 'us' and 'them' (see Afonso 2004: 165). All three films appear to indicate that there seems to exist, as Appadurai has suggested for the concept of the national in the era of globalization, a deep "uncertainty about the ethnic self" (see Appadurai 1999: 322). If "the media," as Higson maintains, "are vital to the argument that modern nations are imagined communities" and "contemporary media activity is also clearly one of the main ways in which transnational cultural connections are established" (see Higson 2000: 66), the three films also offer models for recasting Swiss identity after the loss of a key element of national narrative.

\section{Notes}

1. Im Juli (In July, Germany, 2000) directed by Fatih Akin; Bandits (Germany - France, 1997) directed by Katja von Garnier, Leningrad Cowboys Go America (Finland-Sweden, 1989) directed by Aki Kaurismäki, A köldum klaka (Cold Fever, USA - Japan - Iceland - Denmark - Germany) directed by Fridrik Thor Fridrikson, to name a few. In addition, a growing number of road movies is beginning to question imagined national homogeneity or are outright critical of immigration restrictions and treatment of immigrant minorities: See, for example: Las Cartas de Alou (Letters from Alou, Spain, 1990) directed by Montxo Armendáriz about African immigrants illegally crossing the Mediterranean to live in Spain, Anansi - Der Traum von Europa (Dream of Europe, Germany, 2002) directed by Fritz Baumann about West Africans illegally making their 
way through North Africa and Spain to Germany, and La Citadelle Europe (Citadel Europe, France, 2004) directed by Gilles de Maistre about two Beninese students looking for work in Europe who end up being incarcerated along the way.

2. Mazierska critiques Lisbon Story (Germany-Portugal, 1994) directed by Wim Wenders and Zugvögel - ... einmal nach Inari (Trains n’ Roses, Germany-Finland, 1998) directed by Peter Lichtefeld.

3. This statement pertains to Armendáriz', Baumann's and Gilles de Maistre's films as well as road movies about immigrants traveling to the U.S. See, for example: El Norte (The North, Great Britain-USA, 1983) directed by Gregory Nava and Maria Full of Grace (USA-Colombia, 2004) directed by Joshua Marston.

4. Most notably in Markus Imhoof 's film Das Boot ist voll (The Boat is full, Switzerland-West GermanyAustria, 1981) about anti-Semitic Swiss refugee policies during World War II.

5. See also the documentaries, which traced Switzerland's dealings with the Third Reich and anti-Semitic refugee politics: Kaspar Kasics' Closed Country (Switzerland, 1999) and Eine Reise nach Genf (A Journey to Geneva, Switzerland 2000) directed by Irene Loebell, the story of Austrian author Fred Wander, who fled from the Nazis in 1942.

\section{References}

Afonso, Alexandre. "Immigration and its Impacts in Switzerland." Mediterranean Quarterly 15. 4 (2004): 147-166.

Altermatt, Urs, Bosshart-Pfluger, Catherine, and Albert Tanner. Eds. Die Konstruktion einer Nation. Nationalisierung und Nationalismus in der Schweiz, 18. - 20. Jahrhundert. Zürich: Chronos Verlag, 1998.

Altermatt, Urs. Das Fanal von Sarajewo: Ethnonationalismus in Europa. Zürich: Verlag Neue Züricher Zeitung, 1996

Anderson, Benedict. Imagined Communities: Reflections on the Origins and Spread of Nationalism. London: Verso, 1983.

Appadurai, Arjun. "Dead Certainty: Ethnic Violence in the Era of Globalization." Globalisation and Identity: Dialectics of Flow and Closure. Eds. Birgit Meyer and Peter Geschiere. Oxford: Blackwell, 1999. 305-324.

Bhabha, Homi K. The Location of Culture. London: Routledge, 1994.

Castles, Stephen and Mark Miller. The Age of Migration: International Population Movements in the Modern World. $3^{\text {rd }}$ Edition. Basingstoke and New York: Palgrave, 2003.

Cohan, Steven and Ina Rae Hark. "Introduction." The Road Movie Book. Eds. Steven Cohan and Ina Rae Hark. New York: Routledge, 1997. 1-16.

Festival International du Film sur les Droits Humains, $2^{\text {nd }}$ International Filmfestival on Human Rights in Geneva, March 12-19, 2004, Dec 172004

http://www.fifdh.ch/e/programme/programme_e.html

Gibson, Rachel Kay. The Growth of Anti-Immigrant Parties in Western Europe. Ceredigion/Lewiston, N.Y.: Edwin Mellen Press, 2002.

Häsler, Alfred A. Das Boot is voll. Die Schweiz und die Flüchtlinge 1933-1945. Zürich: Ex libris, 1968. Reprinted: Zürich: Diogenes, 1989.

Higson, Andrew. "The Limiting Imagination of National Cinema." Nation and Cinema. Eds. Mette Hjort and Scott MacKenzie. London/New York: Routledge, 2000. 63-74.

Iordanova, Dina. Displaced? Shifting Politics of Place and Itinerary in International Cinema. Senses of Cinema 14 June 2001. 12 Dec. 2004.

http://www.sensesofcinema.com/contents/01/14/displaced.html

Laderman, David. Driving Visions: Exploring the Road Movie. Austin: University of Texas, 2002. 
Ludi, Regula. Waging War on Wartime Memory: Recent Swiss Debates on the Legacies of the Holocaust and the Nazi Era. Jewish Social Studies 10, 2, Winter 2004: 116-152.

Mazierska, Ewa. "Travelling to the Margins of Europe." Kinema, 16, Fall 2001. 15 January 2005 http://www.arts.uwaterloo.ca/FINE/juhde/mazi-012.htm

Mills, Katie. "Revitalizaing the Road Genre. The Living End as an AIDS road film." The Road Movie Book. Eds. Steven Cohan and Ina Rae Hark. New York: Routledge, 1997. 307-329.

Naficy, Hamid. An Accented Cinema. Exilic and Diasporic Filmmaking. Princeton, NJ: Princeton University Press, 2001.

Todorova, Maria. "The Balkans: From Discovery to Invention." Slavic Review 53, 2 (1994): 453-482.

Wiedmer, Caroline. "Bordering on the Visible: Spatial Imagery in Swiss Memory Discourse." Remembering the Future: The Holocaust in an Age of Genocide. Vol. 3. Ed. Margot Levy. Basingstoke: Palgrave, 2002. 466-477.

\section{Author Information}

Gisela HOECHERL-ALDEN teaches German, Central-European and world cinema, language pedagogy, and folklore in popular culture at the University of Maine. She has published on German-Jewish exiles, the history of German Studies in the United States and second language acquisition. 